\title{
Treatment with tumour necrosis factor inhibitor oxpentifylline does not improve corticosteroid dependent chronic active Crohn's disease
}

\author{
J Bauditz, J Haemling, M Ortner, H Lochs, A Raedler, S Schreiber
}

\begin{abstract}
Background-In Crohn's disease, inflammation is presumably sustained by an increased production of proinflammatory cytokines, in particular tumour necrosis factor $\alpha$ (TNF $\alpha)$ and interleukin $1 \beta$ (IL1ß). TNF $\alpha$ can induce a host of cellular effector events resulting in perpetuation of the inflammatory process. In vivo studies with anti-TNF $\alpha$ antibody treatment have led to impressive clinical results.

Aims-To investigate whether treatment with the TNF $\alpha$ inhibitor oxpentifylline results in clinical improvement in corticosteroid dependent chronic active Crohn's disease.

Methods-Sixteen Crohn's disease patients received oxpentifylline $400 \mathrm{mg}$ four times a day in a four week open label study.

Results-Blockade of TNF $\alpha$ production in 16 patients with corticosteroid dependent Crohn's disease did not improve the clinical disease activity (CDAI mean (SEM) $188.75(5.65)$ versus $185.13(10 \cdot 87)$ or the endoscopic degree of inflammation (CDEIS $14.9(2 \cdot 87)$ versus $14.8(2.27)$ or laboratory parameters.

Conclusions-In this study, use of the TNF $\alpha$ inhibitor oxpentifylline does not improve inflammation in Crohn's disease. This finding suggests that there may be more key mediators than only TNF $\alpha$ in the inflammatory process in Crohn's disease. (Gut 1997; 40: 470-474)
\end{abstract}

Keywords: Crohn's disease, intestinal immunity, tumour necrosis factor $\alpha$, inflammation, oxpentifylline.

Charité University Hospital, 4th Department of Medicine/Mucosal Immunology Unit, Berlin, Germany

J Bauditz

M Ortner

$\mathrm{H}$ Lochs

S Schrieber

Tabea Inflammatory Bowel Disease Center,

Hamburg, Germany

J Haemling

A Raedler

Correspondence to:

Dr S Schreiber,

Ur S Schreiber,

Charité, IV Medizinische

Klinik und Poliklinik,

(Gastroenterology),

Schumannstr 20/21,

Accepted for publication

28 August 1996 leukin $1 \beta$ (IL-1 $\beta) \cdot{ }^{1-8}$ In vitro findings show that $\mathrm{TNF} \alpha$ is capable of inducing a host of proinflammatory effector events, which are thought to be implicated in the pathophysiology of IBD. TNF $\alpha$ has been shown to be involved in neutrophil accumulation, ${ }^{9}$ granuloma formation, ${ }^{10} 11$ upregulation of adhesion mole- cules on endothelial cells, ${ }^{12}$ procoagulant effects, ${ }^{13}$ induction of increased intestinal permeability, ${ }^{14}$ and also has direct cytopathic effects. ${ }^{15}$ TNF $\alpha$ concentrations in serum ${ }^{16}$ as well as stool $^{17}$ and intestinal mucosa ${ }^{125}$ were found to be raised in patients with active Crohn's disease, in comparison with both normal controls and inactive disease. ${ }^{1} 21819$ However, increased transcription and translation of $\mathrm{TNF} \alpha$ is not specific for IBD. ${ }^{20}{ }^{21} \mathrm{In}$ other studies, Isaacs et al could not detect TNF $\alpha$ messenger RNA in a considerable number of biopsy specimens from patients with IBD,${ }^{7}$ and Hyams et $a l^{22}$ did not report increased TNF $\alpha$ values in patients with IBD.

The hypothesis that TNF $\alpha$ may be of particular importance in the induction and perpetuation of intestinal inflammation in IBD and consequently suppression of TNF $\alpha$ should improve inflammation in patients with Crohn's disease was strongly supported by a series of recent therapeutic studies. ${ }^{23} 24$ Experimental treatment of corticosteroid dependent patients with active Crohn's disease by a one time application of a humanised monoclonal antibody directed against TNF $\alpha$ (cA2 IgG1) has generated impressive clinical results. Within four weeks, clinical and endoscopic inflammation completely resolved in eight of 10 patients. ${ }^{24}$ Other pilot studies using a different monoclonal antibody (CDP571) directed against $\mathrm{TNF} \alpha$ could not generate such impressive results. ${ }^{25}$ The CDP571 antibody is from the IgG4 subclass and is therefore theoretically less capable to activate complement in comparison with an IgG1 antibody.

If reduction of TNF $\alpha$ is the exclusive mechanism of action of the $\mathrm{TNF} \alpha \mathrm{cA} 2$ antibody treatment, other drugs that also reduce $\mathrm{TNF} \alpha$ should have similar effects. Oxpentifylline (pentoxifylline, PTX), a xanthinoxidase inhibitor, is a strong suppressor of TNF $\alpha$ release by a host of different cell populations in vitro as well as in vivo. ${ }^{26-33} \mathrm{In}$ dose between $1200 \mathrm{mg} / \mathrm{d}$ and $2000 \mathrm{mg} / \mathrm{d}$, PTX was a strong inhibitor of $\mathrm{TNF}_{\alpha}$ release in vivo and effective in improving $\mathrm{TNF} \alpha$ releated inflammatory disease. ${ }^{27-29} 33$ The presence of corticosteroids potentiates the $T N F \alpha$ inhibitory effect of PTX. ${ }^{34}$ However, as other phosphodiesterase inhibitors PTX has additional contrainflammatory effects, ${ }^{30}{ }^{35}$ some of which cannot be restored by addition of TNF $\alpha$ in vitro. ${ }^{30}$

We treated 16 patients with stable, corticosteroid dependent Crohn's disease with PTX at a dose of $400 \mathrm{mg}$ four times daily in an open label study in which we found no improvement 
of intestinal inflammation or clinical symptoms. The discordance of our findings and those by Dullemen et $a l^{2324}$ raises important questions regarding the mechanism of cA2 anti $\mathrm{TNF} \alpha$ antibody treatment.

\section{Methods}

PATIENTS

Chronic active corticosteroid dependent Crohn's disease was defined by a Crohn's disease activity index (CDAI) between 150-250 and at least $10 \mathrm{mg}$ prednisone daily for a minimum of three months. Patients had to have at least one active episode requiring acute phase treatment ${ }^{36}$ in the preceding six months. Diagnosis of Crohn's colitis or ileocolitis involving at least $30 \mathrm{~cm}$ of the large bowel had to be previously established by radiological, endoscopic, or clinical criteria, ${ }^{37}$ or all three. Only mesalazine (up to a dose of $1 \mathrm{~g}$ thrice daily) and corticosteroids were permitted as antiinflammatory treatment and had to be kept stable two weeks before the study. Use of loperamide or codeine to control diarrhoea was permitted and recorded for calculation of the CDAI. No pain medications, other than tramadol, nutritional therapy (parenteral, formula diets) or immunosuppressives (within the preceding six weeks), were permitted.

Exclusion criteria were bacterial or parasitic pathogens in the patients' stools, a positive Clostridium difficile toxin test, clinical signs of septicaemia, intestinal perforation, megacolon, history of resections other than an ileocaecal resection, signs of stenosis, active fungal or viral infection or when it was felt that patients could not be maintained stable with their present therapeutic regimen for the time of study. Patients were also excluded if they had raised transaminase activities ( $>3$ times normal), hyperbilirubinaemia ( $>2$ times normal), signs of renal dysfunction (serum creatinine $>33 \%$ increased) or a serum cholesterol concentration of less than $100 \mathrm{mg} / \mathrm{dl}$. Informed consent was obtained from all patients. The study was given approval by the local ethics review committee.

Of 152 patients with Crohn's disease seen in the outpatient clinics, 47 patients with chronic active Crohn's disease were screened for inclusion in the study. Of these, 31 patients were excluded for several reasons: a history of bowel surgery other than ileocaecal resection (9), because it was not expected that their corticosteroid treatment would remain stable throughout the study (7), clinical signs of stenosis (6), positive Clostridium difficile toxin testing (1), increased transaminases and bilirubin (1), and signs of renal dysfunction (2). Five patients refused to enter the study. The remaining 16 patients (Table) received oxpentifylline.

\section{BASELINE STUDIES AND FOLLOW UP}

A clinical visit was scheduled two weeks before the tentative start of oxpentifylline treatment and colonoscopy performed within one week before enrolment.

The ability to perform social functions was estimated with a questionnaire according to Robinson et al. ${ }^{38}$ The social function questionnaire consisted of the following seven questions: How much do you feel affected by your disease: (1) in job related activities, (2) in everyday activities in your home, (3) in private activities outside your home, (4) in your general social contacts, (5) in your hobbies/ spare time, (6) in sexual activities, and (7) during sleep. Patients were instructed to mark their answer on a horizontal line of $7 \mathrm{~cm}$ length with the far left side indicating that the social function asked for was not affected and the far right side indicated that it was maximally affected. Measuring the distance from the far left side to the marker the patient set, values could be obtained which reached from 0 (fully capable of performing the social function) to 7 (intense suffering from a total disability to perform the social function).

All patients received oxpentifylline (pentoxifylline (PTX), Trental, Hoechst AG, Frankfurt, Germany) at a dose of $400 \mathrm{mg}$ four times daily orally. This dose range is established as inhibitory for TNF release by trials in AIDS, ${ }^{28}$ bone marrow transplantation ${ }^{27}$ as well as in healthy volunteers. ${ }^{29}$ Patients were seen two and four weeks after start of PTX treatment and at each of these time points, laboratory tests were performed (including $C R P$ and $C$ reactive protein erythrocyte sedimentation rate), a physical examination carried out, and the CDAI calculated. At the four week time point the questionnaire, pertaining to the patient's social functions, ${ }^{38}$ was repeated. After four weeks PTX

Clinical data of patients

\begin{tabular}{|c|c|c|c|c|c|c|c|c|c|c|c|}
\hline Patient & Age (y) & Sex & $\begin{array}{l}\text { Duration of } \\
\text { Crohn's } \\
\text { disease }(y)\end{array}$ & $C D A I$ & CDEIS & $\begin{array}{l}\text { Ileocaecal } \\
\text { resection }\end{array}$ & $\begin{array}{l}\text { Corticosteroid } \\
\text { treatment } \\
\text { (months) }\end{array}$ & $\begin{array}{l}\text { Prednisone } \\
\text { dose (mg) }\end{array}$ & $\begin{array}{l}\text { Extraintestinal } \\
\text { manifestations }\end{array}$ & Mesalazine & $\begin{array}{l}\text { Ileum } \\
\text { involved }\end{array}$ \\
\hline $\begin{array}{l}1 \\
2 \\
3 \\
4 \\
5 \\
6 \\
7 \\
8 \\
9 \\
10 \\
11 \\
12 \\
13 \\
14 \\
15 \\
16\end{array}$ & $\begin{array}{l}23 \\
19 \\
24 \\
20 \\
27 \\
31 \\
56 \\
47 \\
42 \\
41 \\
37 \\
25 \\
18 \\
22 \\
34 \\
29\end{array}$ & $\begin{array}{l}M \\
F \\
F \\
M \\
M \\
F \\
F \\
F \\
M \\
F \\
F \\
M \\
F \\
F \\
M \\
F\end{array}$ & $\begin{array}{c}4 \\
7 \\
5 \\
2 \\
8 \\
5 \\
24 \\
17 \\
2 \cdot 5 \\
4 \cdot 5 \\
11 \\
9 \\
2 \\
1 \cdot 5 \\
7 \\
10\end{array}$ & $\begin{array}{l}167 \\
188 \\
202 \\
187 \\
190 \\
212 \\
232 \\
170 \\
205 \\
212 \\
207 \\
165 \\
152 \\
178 \\
202 \\
151\end{array}$ & $\begin{array}{l}12 \cdot 4 \\
15 \cdot 8 \\
14 \cdot 8 \\
13 \cdot 2 \\
11 \cdot 7 \\
13 \cdot 4 \\
17 \cdot 8 \\
16 \cdot 2 \\
20 \cdot 2 \\
15 \\
13 \cdot 4 \\
18 \cdot 4 \\
19 \\
9 \cdot 6 \\
11 \cdot 6 \\
15 \cdot 4\end{array}$ & $\begin{array}{l}\text { No } \\
\text { No } \\
\text { Yes } \\
\text { No } \\
\text { No } \\
\text { No } \\
\text { Yes } \\
\text { No } \\
\text { Yes } \\
\text { No } \\
\text { No } \\
\text { No } \\
\text { No } \\
\text { No } \\
\text { No } \\
\text { No }\end{array}$ & $\begin{array}{r}7 \\
9 \\
17 \\
12 \\
90 \\
7 \\
144 \\
60 \\
10 \\
14 \\
66 \\
5 \\
6 \\
6 \\
48 \\
30\end{array}$ & $\begin{array}{l}10 \\
15 \\
15 \\
10 \\
10 \\
10 \\
20 \\
15 \\
20 \\
25 \\
20 \\
15 \\
10 \\
10 \\
15 \\
20\end{array}$ & $\begin{array}{l}\text { - } \\
\text { arthralgia } \\
\text { erythema nodosum } \\
\text { arthralgia } \\
\text { arthritis } \\
\text { arthralgia } \\
- \\
\text { arthralgia } \\
= \\
= \\
\text { - } \\
\text { arthritis }\end{array}$ & $\begin{array}{l}\text { Yes } \\
\text { Yes } \\
\text { Yes } \\
\text { Yes } \\
\text { Yes } \\
\text { Yes } \\
\text { No } \\
\text { Yes } \\
\text { Yes } \\
\text { Yes } \\
\text { Yes } \\
\text { Yes } \\
\text { Yes } \\
\text { Yes } \\
\text { Yes } \\
\text { Yes }\end{array}$ & $\begin{array}{l}\text { Yes } \\
\text { Yes } \\
\text { Yes } \\
\text { No } \\
\text { Yes } \\
\text { Yes } \\
\text { Yes } \\
\text { Yes } \\
\text { Yes } \\
\text { No } \\
\text { Yes } \\
\text { Yes } \\
\text { Yes } \\
\text { No } \\
\text { Yes } \\
\text { Yes }\end{array}$ \\
\hline
\end{tabular}


medication was stopped and a repeat colonoscopy was performed (trial end \pm 3 days).

Patients were informed to increase or decrease their corticosteroid dose in a range of $\pm 10 \mathrm{mg}$ on demand. Corticosteroid use was protocolled in patients diaries. All patients who worsened during the trial (by an increase in CDAI of $>50$ points or by physicians global assessments), were treated appropriately by increasing the daily dose of prednisone. In this case PTX was stopped. Patients who stopped their medication because of adverse reaction (none) or treatment failure (four), were followed up in the same way as those who continued to receive PTX. The primary outcome measure was the induction of clinical remission, as defined by decrease of the CDAI below 150 , but at least by 50 points. Secondary outcome measures were changes in CDAI, Crohn's disease endoscopic index (CDEIS), ${ }^{39}$ the ability to reduce prednisolone treatment, and improvement of social functions.

IN VITRO CYTOKINE STUDIES

Fetal calf sera and pokeweed mitogen were purchased from Gibco (Grand Island, NY). TNF $\alpha$, IL1 $\beta$, and IL6 ELISA kits were obtained from R\&D/DPC Biermann (Bad Nauheim, Germany). All other chemicals were obtained from Sigma if not specified differently. Peripheral blood mononuclear cells (PBMNC) or peripheral blood monocytes were isolated as previously described, ${ }^{40}$ cultured in the presence of pokeweed mitogen ( $1 \% \mathrm{vol} / \mathrm{vol}, 24$ hours), and supernatant cytokine values determined in duplicate by ELISA.

STATISTICS

Results are expressed as mean (SEM). Statistical significance of differences was tested by non-parametric Spearman correlation ${ }^{41}$ or the Mann-Whitney $U$ test.

\section{Results}

DISEASE ACTIVITY AND INFLAMMATION PARAMETERS

CDAI scores did not change significantly during the treatment period $(188.75(5.65)$ before versus $185 \cdot 13(10 \cdot 87)$ after treatment; Figure). Four patients stopped PTX treatment because of increased disease activity. None of the patients could discontinue prednisone during PTX treatment, five patients reduced prednisone by $5 \mathrm{mg}$ daily, and five patients increased prednisone use. Overall, prednisone use on a cumulative basis was not changed significantly by PTX treatment $(15(4 \cdot 68)$ before $(n=16)$, versus $12 \cdot 5(2 \cdot 5)$ after treatment $(n=12))$.

Crohn's disease endoscopic index before and after treatment with PTX did not change significantly $(14.9 \quad(2 \cdot 87)$ before treatment $(n=16)$ versus $14.8(2 \cdot 27)$ after treatment $(n=12)$, Figure). All four patients who had to stop PTX treatment because of increased clinical activity, did have higher than average CDEIS scores at study begin (16.6 mean).

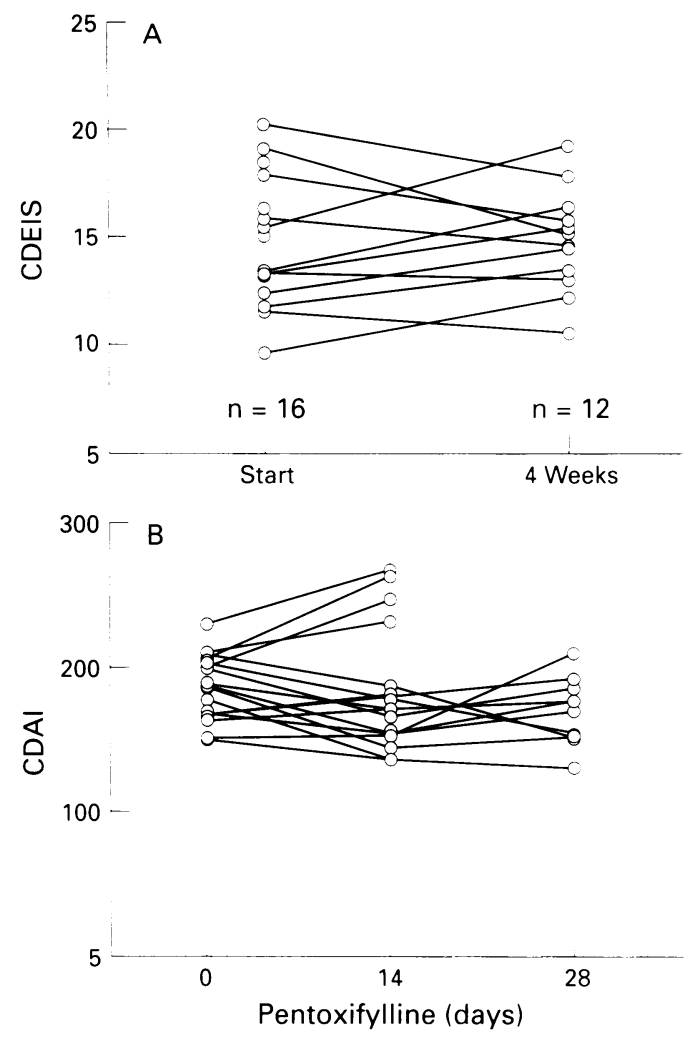

CDEIS and CDAI under treatment with oxpentifylline. CDEIS scores before and after treatment with oxpentifylline appeared to be unchanged. (A) Average CDEIS scores were $14.9(2.87)$ before $(n=16)$ and $14.8(2.27)$ after treatment $(n=12)$. In four patients oxpentifylline had to be stopped after two weeks because of an increased disease activity. (B) CDAI scores before treatment with oxpentifylline ranged between 150-250. During the trial no significant improvement was observed.

Serum concentrations of $\mathrm{C}$ reactive protein $(27 \cdot 1)(14.7)$ before treatment versus 35.2 $(17 \cdot 5)$ after treatment) and erythrocyte sedimentation rate $(22.8(4.6)$ before treatment versus $28.6(5.4)$ after treatment) did not change significantly.

None of the patients receiving oxpentifylline treatment experienced severe side effects.

EFFECTS OF PTX ON TNF $\alpha$ PRODUCTION

In six patients $\mathrm{TNF} \alpha$ secretion by peripheral monocytes was studied before and at the end of PTX treatment $(35.8(13.9) \mathrm{pg} / \mathrm{ml}$ before treatment versus 13.2 (19) after treatment, non-significant). All patients had detectable $\mathrm{TNF} \alpha$ production before PTX, in five patients it decreased below the sensitivity range, although in two patients values were already at the lower detection limit before PTX treatment. In one patient $\mathrm{TNF} \alpha$ release was not inhibited by PTX.

Five healthy volunteers received oxpentifylline $400 \mathrm{mg}$ four times daily for a period of two days. Release of $\mathrm{TNF} \alpha$ by $10^{6} \mathrm{PBMC} / \mathrm{ml}$ stimulated with lipopolysaccharide $(1 \mu \mathrm{g} / \mathrm{ml}$ for 24 hours) was significantly suppressed by in vivo PTX in comparison with baseline values (1068 (198) before, 251 (122) $\mathrm{pg} / \mathrm{ml}$ after two days oxpentifylline; $p=0.008)$. In contrast, secretion of IL1 $\beta$ (324 (66) versus 350 (62) $\mathrm{pg} / \mathrm{ml}$ ) and IL6 (2124 (311) versus 2252 (225) $\mathrm{pg} / \mathrm{ml}$ ) did not change significantly. 
SOCIAL FUNCTION SCORES

Social function scores showed that cotreatment with oxpentifylline did not significantly improve the patient's social functions except for sleep disturbance (week 0:3.6 $(0.35) \quad(n=16)$, score week 4: $2.4 \quad(0.29)$ $(n=12), p=0.017)$. Upon detailed interviewing most patients indicated retrospectively that improvement of sleep was due to reduced muscle aches and reduced night sweat.

\section{Discussion}

Chronic inflammatory activity in Crohn's disease may be sustained by the local release of proinflammatory cytokines from intestinal macrophages and $T$ cells including secretion of $\mathrm{TNF} \alpha$, IL1 $\beta$, and IL6. ${ }^{3} 131420-21$ As TNF $\alpha$ is a potent proinflammatory mediator, which can be released by mononuclear phagocytes, activated $\mathrm{T}$ cell subpopulations as well as invading granulocytes $^{42}$ the specific blockade of TNF $\alpha$ has been considered a promising approach for treatment of intestinal inflammation. ${ }^{23} 24$ Strong support for this hypothesis has been given by experimental treatment of chronic active corticosteroid dependent Crohn's disease with a one time application of a monoclonal antibody (cA2) directed against $\mathrm{TNF} \alpha$, which induced complete endoscopic and clinical remission in eight of 10 patients within four weeks. ${ }^{23}{ }^{24}$ These findings may indicate a pivotal role of TNF $\alpha$ in the pathophysiology of intestinal inflammation in Crohn's disease.

To test this hypothesis we specifically blocked $\mathrm{TNF} \alpha$ production by another agent, oxpentifylline, which is an established inhibitor of TNF $\alpha$ release in vitro as well as in vivo. ${ }^{26-34}$ Oxpentifylline has therefore been used in dose from 1200 to $2000 \mathrm{mg} / \mathrm{d}$ in clinical trials to suppress presumable in vivo effects of TNF $\alpha .{ }^{27-29} 33$ However, in common with other phosphodiesterase inhibitors, PTX may have also additional contrainflammatory effects including a reduction of $\mathrm{T}$ lymphocyte cytokine secretion (that is, IFN $\gamma$ ) in vitro. ${ }^{30} 35$

In contrast with anti-TNF $\alpha$ cA2 antibody treatment no effect by PTX could be seen on clinical, laboratory or endoscopic activity. With the exception of sleep disturbance by the disease, none of the social functions assessed by a questionnaire improved. However, upon a detailed interview most patients indicated retrospectively that improvement of sleep was due to reduced muscle aches and reduced night sweat. These are both symptoms that may be attributed to raised TNF $\alpha$ levels. ${ }^{43}$

The negative results of PTX treatment suggest that the mechanism of anti-TNF $\alpha$ antibody treatment (using the monoclonal antibody cA $2^{23}{ }^{24}$ supplied by Centocor, PA, USA) in Crohn's disease may not only relate to a specific blockade of $\mathrm{TNF} \alpha$ secretion. Other mechanisms including complement mediated lysis of cells expressing membrane bound TNF $\alpha^{44}$ may possibly contribute to its efficacy. Thus, the cA2 antibody could also inhibit mediators apart from $\mathrm{TNF} \alpha,{ }^{46}$ which may sustain chronic intestinal inflammation. Taken together, our findings and the findings of Derkx $e t a l^{23}{ }^{24}$ may indicate that there are more key mediators than only $\mathrm{TNF} \alpha$ in the inflammatory process in Crohn's disease.

It is not known how much suppression of $\mathrm{TNF} \alpha$ is actually induced in the mucosal compartment by either cA2 anti-TNF antibody treatment or by PTX. Moreover, the possibility exists that a substantial proportion of mucosal TNF $\alpha$ originates from T cells, and inhibition of TNF production by mucosal $T$ cell populations by PTX has not been investigated yet. Finally, although selection criteria were similar in both trials, Derxx et $a l^{23}{ }^{24}$ investigated in their uncontrolled pilot study a more active patient population (as indicated by the higher average CDAI) than we did. Therefore, patients' mucosal TNF $\alpha$ levels may have been different between both trials.

Further studies are necessary to clarify the relevance of mucosal TNF $\alpha$ production in the pathophysiology of inflammation in Crohn's disease. In this pilot trial, oxpentifylline at a dose of $400 \mathrm{mg}$ four times daily given over a period of four weeks was not effective in treating patients with corticosteroid dependent chronic active Crohn's disease. Further controlled studies are warranted to examine the therapeutic potential of oxpentifylline and other TNF $\alpha$ inhibitors in Crohn's disease.

The excellent technical help of Anna Maria Wenner and Stefan Eidner is gratefully acknowledged. This work was supported by a grant from the Deutsche Forschungsgemeinschaft (SCHR $512 / 1-2$ ) and by a grant from Syngen Pharma GmbH. Parts of the study were presented at the $97^{\text {th }}$ annual meeting of the American Gastroenterological Association in San Francisco (Gastroenterology 1996; 110: A861).

1 Mahida YR, Wu $K$, Jewell DP Enhanced production of interleukin $1-\beta$ by mononuclear cells isolated from interleukin $1-\beta$ by mononuclear cells isolated from Gut 1989; 30: 835-8.

2 Ligumsky M, Simon PL, Karmeli F, Rachmilewitz D. Role of interleukin 1 in inflammatory bowel disease - enhanced production during active disease. Gut 1990; 31: 686-9.

3 MacDonald TT, Hutchings P, Choy MY, Murch S, Cooke A. Tumour necrosis factor-alpha and interferon-gamma production measured at the single cell level in normal and inflamed human intestine. Clin Exp Immunol 1990; 81: 301-5.

4 Schreiber S, MacDermott RP, Raedler A, Pinnau R, Bertovich M, Nash GS. Increased activation of intestinal lamina propria mononuclear cells in inflammatory bowel lamina propria mononuclear cells in inflamm

5 Schreiber S, Heinig T, Panzer U, Reinking R, Bouchard A, Stahl PD, et al. Impaired response of activated mononuclear phagocytes to interleukin 4 in inflammatory bowel disease. Gastroenterology 1995; 108: 21-33.

6 Stevens C, Walz G, Singaram C, Lipman ML, Zanker B, Muggia $A$, et al. Tumor necrosis factor- $\alpha$, interleukin- $1 \beta$ and interleukin 6 expression in inflammatory bowel disease. Dig Dis Sci 1992; 37: 818-26.

7 Isaacs KL, Sartor RB, Haeskil JS. Cytokine messenger RNA profiles in inflammatory bowel disease detected by polymerase chain reaction amplification. Gastroenterolog 1992; 103: 1587-95.

8 Dinarello CA, Wolff SM. The role of interleukin 1 in disease. $N$ Engl f Med 1993; 328: 106-13.

9 Rampart M, De Smet W, Fiers W, Herman AG. Inflammatory properties of recombinant tumor necrosis in rabbit skin in vivo. $\mathcal{F}$ Exp Med 1989; 169: 2227-32.

10 Kindler V, Sappino AP, Gran GE, Piguet PF, Vassali P. The inducing role of tumor necrosis factor in the developmen of bactericidal granulomas during BCG infection. Cell 1989; 56: $731-40$.

11 Amiri P, Locksley RM, Parslow TG, Sadick M, Rector E, Ritter D, et al. Tumor necrosis factor alpha restores granulomas and induces parasite egg-laying in schistosome-infected SCID mice. Nature 1992; 356: 604-7.

12 Clauss M, Ryan J, Stern D. Modulation of endothelial cell hemostatic properties by TNF. Insights into the role of endothelium in the host response to inflammatory role of endothelium in the host response to inflammatory stimuli. In: Beutler B, ed. Tumor necrosis factors: The molecules and their emerging

13 Sun XL, Hsueh W. Bowel necrosis induced by tumor necrosis factor in rats is mediated by platelet-activating necrosis factor in rats is mediated by 
14 Mullin JM, Snock KV. Effect of tumor necrosis factor on epithelial tight junctions and transepithelial permeability. Cancer Res 1990; 50: 2172-6.

15 Deem RL, Shanahan F, Targan SR. Triggered human mucosal $\mathrm{T}$ cells release tumor necrosis factor-alpha and interferon-gamma which kill human colonic epithelial cells. Clin Exp Immunol 1991; 83: 79-84.

16 Murch SH, Lamkin VA, Savage MO, Walker-Smith JA, MacDonald TT. Serum concentrations of release tumor necrosis factor-alpha in childhood chronic inflammatory bowel disease. Gut 1991; 32: 913-7.

17 Braegger CP, Nicholls SW, Murch SH, Stephens S, MacDonald TT. Tumor necrosis factor alpha in stool as a marker of intestinal inflammation. Lancet 1992; 339: $89-91$.

18 Schreiber S, Koop I, Bauditz J, Nikolaus S, Lochs $H$. Increased secretion of proinflammatory cytokines by LPMNC is a predictor for relapse of IBD Gastroenterolog 1995; 108: A332.

19 Stevens C, Walz G, Singaram C, Lipman ML, Zanker B, Muggia A, et al. Tumor necrosis factor $\alpha$, interleukin $1 \beta$ and interleukin 6 expression in inflammatory bowel disease. Dig Dis Sci 1992; 37: 818-26.

20 Capello M, Keshav S, Prince C, Jewell DP, Gordon S. Detection of mRNAs for macrophage products in inflammatory bowel disease by in situ hybridisation. Gut 1992; 33: $1214-9$.

21 Breese EJ, Michie CA, Nicholls SW, Murch SH, Williams CB, Domizio $\mathrm{P}$, et al. Tumor necrosis factor $\alpha$-producing cells in the intestinal mucosa of children with inflammatory bowel disease. Gastroenterology 1994; 106: 1455-65.

22 Hyams JS, Treem WR, Eddy E, Wyzga N, Moore RE. Tumor necrosis factor alpha is not elevated in children with inflammatory bowel disease. $\mathcal{F}$ Pediatr Gastroenterol Nuth 1991; 12: 233-6.

23 Derkx B, Taminiau J, Radema S, Stronkhorst A, Wortel C, Tytgat $\mathrm{G}$, et al. Tumor-necrosis-factor antibody treatment Tytgat G, et al. Tumor-necrosis-factor antibody

24 van Dullemen HM, van Deventer SJH, Hommes DW, Bijl HA, Jansen J, Tytgat GNJ, Woody J, et al. Treatment of Crohn's disease with anti-tumor necrosis factor chimeric antibody (cA2). Gastroenterology 1995; 109: 129-35.

25 Stack W, Mann S, Roy A, Heath P, Sopwith M, Freeman J, et al. The effects of CDP571, an engineered human IgG4 anti-TNF-alpha antibody in Crohn's disease. Gastroenterology 1996; 110: A1018.

26 Strieter RM, Remick DG, Ward PA, Spengler RN, Lynch JP, Larrick J, et al. Cellular and molecular Lynch JP, Larrick J, et al. Cellular and molecular
regulation of tumor necrosis factor-alpha production by regulation of tumor necrosis factor-alpha production by pentoxifylli

27 Bianco JA, Appelbaum FR, Nemunaitis J, Almgren J, Andrews F, Kettner P, et al. Phase I-II trial of pentoxifylline for the prevention of transplant-related toxicities following bone marrow transplantation. Blood 1991; 78: 1205-11

28 Dezube BJ, Pardee AB, Chapman B, Beckett LA, Korvick JA Novick WJ, et al. Pentoxifylline decreases tumor necrosis factor expression and serum triglycerides in people with AIDS. Fournal of Aquired Immunodeficiency Syndrome 1993; 6: 787-94.

29 Neuner P, Klosner G, Schauer E, Pourmojib N, Macheiner W, Grünwald $C$, et al. Pentoxifylline in vivo down-regulates the release of IL-1 $\beta$, IL-6, IL- 8 and tumor necrosis factor the human peripheral blood mononuclear cells. by human peripheral blo
Immunology 1994; 83: $262-7$.
30 Tilg H, Eibl B, Pichl M, Gächter A, Herold M, Brankova J, et al. Immune response modulation by pentoxifylline in vitro. Transplantation 1993; 56: 196-201.

31 van Leenen $D$, Vanderpoll $T$, Levi $M$, Tencate $H$, van Deventer SJH, Hack CE, et al. Pentoxifylline attenuates neutrophil activation in experimental endotoxinemia in chimpanzees. F Immunol 1993; 151: 2318-25.

32 Breuillé D, Farge MC, Rosé F, Arnal M, Attaix D, Obled C. Pentoxifylline decreases body weight loss and muscle protein wasting characteristics of sepsis. Am 7 Physiol 1993; 265: E660-6.

33 Attal M, Huguet F, Rubie H, Charlet JP, Schlaifer D, Huynh A, et al. Prevention of regimen-related toxicities after bone marrow transplantation by pentoxifylline: a prospective, randomized trial. Blood 1993; 82: 732-6.

34 Han J, Thompson P, Beutler B. Dexamethasone and pentoxifylline inhibit endotoxin-induced cachectin/tumor factor synthesis at separate points in the signalling pathway. $\mathcal{F}$ Exp Med 1990; 172: 391-4

35 Kovach NL, Lindgren CG, Fefer A, Thompson JA, Yednock T, Harlan JM. Pentoxifylline inhibits integrinmediated adherence of interleukin-2 activated human peripheral blood lymphocytes to human umbilical vein peripheral blood lymphocytes to human umbilical vein
cells, matrix components, and cultured tumor cells. Blood cells, matrix componer

36 Summers RW, Switz DM, Sessions JT Jr, Becktel JM, Best WR, Kern J Jr, et al. National cooperative Crohn's disease Study: Results of drug treatment. Gastroenterology 1979; 77: 847-69.

37 Malchow H, Ewe K, Brandes JW, Goebell H, Ehms H, Sommer H, et al. European cooperative Crohn's disease study (ECCDS): Results of drug treatment. Gastroenterology 1984; 86: 249-66.

38 Robinson M, Hanauer S, Hoop R, Zbrozek A, Wilkinson C. Mesalamine capsules enhance the quality of life for patients with ulcerative colitis. Aliment Pharmacol Ther 1994; 8: $27-34$.

39 GETAID represented by Mary JY and Modigliani R. Development and validation of an endoscopic index of the severity for Crohn's disease: A prospective, multicentre study. Gut 1989; 30: 983-9.

40 Reinecker HC, Steffen M, Witthöft T, Pflueger I, Schreiber S, MacDermott RP, et al. Enhanced secretion of tumor necrosis factor-alpha, IL- 6 and IL- 1 beta by isolated lamina propria mononuclear cells from patients with ulcerative colitis and Crohn's disease. Clin Exp Immunol 1993; 94: 174-81.

41 Sachs L. Angewandte Statistik. 7 th ed. Heidelberg: Springer, 1992

42 Nikolaus S, Hampe J, Bauditz J, Ortner M, Reichelt E, Lochs $\mathrm{H}$, et al. Pivotal role of granulocytes in immunoregulation in inflammatory bowel disease? Gut 1996; 39 (suppl 3): A2.

43 Dinarello CA. Interleukin-1 and tumor necrosis factor and their naturally occuring antagonists during hemodialysis. Kidney Int Suppl 1992; 38: S68-77.

44 Kriegler M, Perez C, DeFay K, Albert I, Lu SD. A novel form of TNF/cachectin is a cell surface cytotoxic transmembrane protein: ramifications for the complex physiology of TNF. Cell 1988; 53: 45-53.

45 Scallon BJ, Moore MA, Trinh DM, Ghrayeb J Chimeric anti-TNF- $\alpha$ monoclonal antibody, cA2 binds recombinant transmembrane TNF- $\alpha$ and activates immune effector functions. Cytokine 1995; 7: 251-9.

46 Todorov P, Cariuk P, McDevitt T, Coles B, Fearon K, Tisdale $M$. Characterization of a cancer cachectic factor. Nature 1996; 379: 739-42. 